\title{
Passing over Sisters: Denial of Farhadi's Unsafe Society
}

\author{
Ma'soome Sehat \\ English Department, Yazd University, Yazd, Iran \\ Hossein Jahantigh \\ English Department, Yazd University, Yazd, Iran
}

\begin{abstract}
Employing semiology to study the academy award-winning director, Asghar Farhadi's oeuvre up to 2016, this paper wishes to scrutinize his depicted society through the lens of feminism. His female characters' lifestyle and their way of thinking show they always feel uneasy in Farhadi's depicted society. It defines woman the same as what other patriarchal societies do, an object in need of protection. In this undesirable condition, women are expected to back their sisters up; however, the opposite is true about nearly all female characters in Farhadi's cinema. They usually live while denying each other as a sort of defense mechanism, and after Farhadi's famous accidents, there is always one or more female characters putting the blame on the female victim of the accident, technically speaking, referred to as victim-blaming. This paper wants to seek a psychological answer for this unusual behavior. In this regard, seven movies have been chosen including: Dancing in the Dust (2003), Beautiful City (2004), Fireworks Wednesday (2006), About Elly (2009), A Separation (2011), The Past (2013), and The Salesman (2016).
\end{abstract}

Index Terms - defense mechanism, denial, Farhadi, feminism, objectification, society, semiology, victimblaming

\section{INTRODUCTION}

The depicted society in Farhadi's cinema is unsafe for women. It does not matter where the story is set and which class of society is involved, all women are in danger of being abused. Haunted with the fear of infamy, they have to keep part of the reality of their life secret from other members of society, including their husbands. It seems woman is considered an object in this society whose value is subject to question easily. Therefore, a woman is always in need of a man's protection, who is not, necessarily, stronger than the woman, herself. While a male character in all Farhadi's movies tries his best to back the central female character, she finds other women tormenting her life. In this respect, this paper seeks, in its first part, to identify what the unsafe depicted society of Farhadi looks like and in its second part, to argue the impression of female characters' behavior in embittering of this harrowing experience and the possible psychological reason behind it. With the defense mechanism of denial, they can ignore the unsafety of their society and victim-blaming helps them keep distance with the women involved in the accidents.

Many researchers have found Farhadi's life and career interesting as their field of study by virtue of his winning of two academy awards. A major or a significant part of most of these pieces of research are allocated to feminine issues, since, a social problem, centralizing a woman, is always typical of his works. Tina Hassannia (2014) in her book entitled Asghar Farhadi: Life and Cinema has presented six articles about Farhadi's first directed movies, prefaced by an exclusive interview with the director himself. The third article of her book entitled "When I became a woman" has chosen Fireworks Wednesday and its female characters as the subject of study. She has analyzed the movie centralizing Rouhi, the young servant. Although her article has the feministic perspective in common with ours, its center of attention is the clash of different classes of society rather than women. Moreover, in his comparative study, Kambiz Partazian has used the same movie to analyze Iranian society in three decades of the 1360s, 70s, and 80s (corresponding with the Western Calendar 1980s, 1990s and the first decade of $21^{\text {st }} \mathrm{c}$ ). He has deduced that women have undergone the most radical changes during the aforementioned modern period.

Mehra Shirazi, Patti Duncan and Kryn Freehling-Burton (2017) in an article entitled "Gender, Nation and Belonging: Representing Mothers and Maternal in Asghar Farhadi's A Separation," have had a close reading of A Separation from a feminist perspective. They believe that in this movie "the discourse of gender and nation are being negotiated" (p. 84). However, the contribution of this paper to the existing literature is that it tries to consider Farhadi's oeuvre up to 2016, by analyzing the issue of woman against woman.

In this regard, semiology is employed as the method of analyzing these movies to disclose their latent meanings, because this approach tends to "elucidate [codes], make them explicit [and] establish them as objects while in nature they remain buried in the film" (Metz, 2011, p. 47). Additionally, a semiotic study "is not only the sum of films but also the unique and sovereign code which is assumed to be coextensive with all semantic material provided by [the] films" (Metz, 2011, p. 27). Therefore, for syntagmic aspect of semiology (relation of units) scenes are zoomed on. For 
paradigmatic one "association whereby the signifier has chosen to represent the signified in similarity or relation to other signifiers" (Roth, 2013, p.19), different semiotic elements of these movies, including frames, scenes and especially dialogues are scrutinized. By doing this, different signs of the unsafe society and women's feelings toward patriarchal societies are decoded.

Before going over the methodology of the paper and by virtue of the great number of the selected movies it is proper to render a plot synopsis of them. Farhadi's oeuvre includes movies that focus on similar social issues. For instance, almost all of his female characters are dealing with the same problems. Dancing in the Dust is the first in this line. This movie tells the story of Reyhane and Nazar, newly married, but forced to break up their marriage. The society has labeled Reyhane's mother as a prostitute and having relationship with such a girl will ruin Nazar's life. Despite all his love, Nazar, eventually puts an end to this marital relationship. His mother has a crucial effect on him to change his mind and make this decision. After separation, Reyhane is doomed to follow her mother, as Nazar has predicted. A woman ruins another one's promising future, what can be traced in Farhadi's second movie, as well.

In Beautiful City, Firooze's dream to marry Aa'la cannot be fulfilled because of Abolghasem's wife's suggestion. Aa'la goes to great lengths to save his fellow inmate, Akbar, Firooze's brother, sentenced to execution for murdering Abolghasem's daughter. With Abolghasem's consent, his punishment can be changed. Abolghasem's wife suggests that she will get his consent if Aa'la marries her disabled daughter. With such a proposition, she puts Rehyane in a dilemma between Aa'la's love and Akbar's life, choosing any of which is going to ruin her future. Main female characters in The Fireworks Wednesday share similar feelings. Simin feels guilty because of having a love affair with Mojde's husband, but it is too difficult to break up with a man who adores her. Mojde, on the other hand, goes on living with Morteza although she is aware of his infidelity, while all other women treat them as criminals.

Simin in A Separation, does not have her mother's support for getting divorce. However, she leaves her husband, Nader, and goes back to her mother's house. In Simin's absence, Nader employs a servant called Razie to help him nursing his sick father. Having come back home sooner, once, Nader finds his father in a bad situation, which makes him to burst into anger and throw Razie out of house. The same night Razie aborts her child. Everybody puts the blame on Nader, although she is not sure. Like Simin, Razie cannot find other women supportive of her decision and feelings. Her sister-in-law stops her telling the truth and the woman in Nader's neighborhood and his daughter's teacher testify against her.

About Ellie portrays a lovely girl called Ellie. She has accepted to go on a trip with Sepide to get familiar with Ahmad. On the trip, she goes to the sea and gets drowned. Meanwhile, Sepide and her friends who do not know what exactly has happened to her, start making gossips. They assume her as a poor girl and finally Sepide ruins all her reputation with her lie. She tells Ellie's fiancé that Ellie never talked about him which means Sepide did not know about their engagement while inviting Ellie to the trip.

Almost all female characters in The Past lack the support of other women. Naeema who works in a laundry shop is suspected by Celine to have love relationship with her husband. Both these women worsen each other's situation, which ends in Celine's suicide. Marian, on the other hand, is the one with whom Celine's husband is in love. Other female characters, especially her daughter, ignore her feelings, too. Lucie sends her mother's love letter to Celine. No woman in this movie understands another one. The same is true about The Salesman's atmosphere. Ra'na pays no attention to women around her. Sanam, her copartner in the play is one of these women. When one male copartner teases her, Ra'na cannot help laughing. Ahoo is another woman ignored by Ra'na. She used to live in the house to which Ra'na and her husband want to move. She opens the door of Ahoo's room and asks her friend to put her stuff in the yard. In thirtieth moment of the movie, however, an accident changes her situation. She gets assaulted by a strange man who enters their house. After this accident, she feels a hard time that other women cannot understand. Azita, the director, plays her role in the play on stage without informing her and Sanam asks her to behave normally.

\section{METHODOLOGY}

Semiology is the science of constructing a comprehensible model to explain the signified meaning to an audience (Roth, 2013, p. 8). As one of the first critical methods applied to cinema, it considers cinema a composite language system, and defines film as a unit of discourse.

To Metz, the foremost film semiotician, discourse is a series of statements rather than the language itself. In his book entitled Language and Film, Metz (2011) offers five film facts appropriate for semiotic studies, namely, "the visual image, the musical sound, the verbal sounds of speech, sounds effects and the graphic form of credits." He believes that by scrutinizing these features, a semiotic analysis can go through theme or "the internal organization of meaning underlying a given film" (p. 16), which is exactly what this paper tries to do by decoding Asghar Farhadi's discourse from a feminist viewpoint. Therefore, different signifiers of the patriarchal society in his directed movies up to 2016 and their influence on the characters, especially the female ones, are explained.

Moreover, considering film as a social phenomenon, semiology desires to leave the study of film facts to external issues and related disciplines such as social science and psychology. Thus, "victim-blaming" as a category belonging to the former and defense mechanism of "denial," a term belonging to the latter one, are employed to clarify the behavior of Farhadi's female characters. 


\section{The UnSAFE SOCIETY AND OBJECTIFICATION OF WOMEN}

Farhadi's depicted society is not safe for his female characters. As the conversation of the two sisters in Fireworks Wednesday indicates:

Mahshid: Wherever you go, it's unsafe darling, it's all the same.

Mojde: Even when you are out, you feel nervous to come back. (Saadatian \& Farhadi, 2006, 00:27:51)

Some women like Mahshid are accustomed to such a situation while many others like Mojde are always complaining about it, and still there are others such as Simin in A Separation and R'ana of The Salesman who try to escape from it or at least ignore it.

Farhadi tends to sketch his story's shreds of evidence in the patriarchal society with male dominance and female submission. The inferiority of woman in patriarchal societies leads to her objectification. Andrea Dworkin has described it thus:

Objectification is a social process that occurs when a perpetrator in a being, through social means, is made less than human, turned into a thing or commodity, bought and sold. When objectification occurs, a person is depersonalized, so that no individuality and integrity is available socially or in what is an extremely circumscribed privacy. (as quoted in Riddle, 2015)

Women stand at the very bottom of the hierarchy of power in patriarchal society and therefore male members of society can use them like an object. Objectification is not just a social phenomenon but a way of thinking through which people's perspective toward life can be defined; a perspective familiar to Farhadi's characters. They act as if they accept objectification as a harsh fact. In this part of the paper, four of the social consequences of such a perspective are presented with examples from Farhadi's cinema: 1. Objectification puts women under lasting gamic observation of men; 2. It also lets others judge them easily; which means that 3. A man should always protect them; or 4. Society forces them to infamy.

Firstly, in Farhadi's depicted society, female characters are always under gamic observation of males. The famous French feminist, Simon De Beauvoir suggests that "patriarchal societies define a woman as the other, as not much more than her body, as "the object for the gaze and touch of a subject, to be the pliant responder to his command" (as quoted in Bulbeck, 1997, p. 26). She indicates that in a patriarchal society, woman is an object in service of man's needs. Thus, men are allowed to enjoy this object, annoying them, though.

The unsafe society for women is depicted stereotypically and recurrently in almost all the selected movies: Nazar of Dancing in the Dust in the scene of departing from Reyhane, asks the man in the taxi to swap his seat with Reyhane to protect her from men's sidelong glances. In the sequence of bus in Beautiful City, A'ala protects Firooze by stopping a boy gazing at her. The woman next to Emad of The Salesman in the taxi seems to have had a similar experience while asking the driver to swap her seat. Emad, later on, explicates her behavior to his student thus: "For sure, a man must have irritated her once" (Mallet-Gay \& Farhadi, 2016, 00:22:47).

As Kiang (2017) has mentioned: The Salesman "is a film about the mistrust and fear of women by men, especially the dangerous mystery of their sexual allure." No woman feels safe in The Salesman's atmosphere. Sanam finds playing in the theater a risky job, but needs the money; Ra'na's neighbors are worried to live next to a prostitute and the woman in the taxi, as mentioned before, cannot stand sitting close to a man. On the other hand, different male characters' behavior in this movie, regardless of their age, attests to this fear. Siavash's sexual mindset makes him burst into laughter at Sanam playing a prostitute role; Emad's student seems to have erotic pictures in his cell phone and Babak is in secret relationship with Ahoo, the prostitute formerly residing in the same new house of R'ana and Emad, belonging to Babak. However, nothing can describe this "dangerous mystery" more explicitly than the old man addressing his transgression against R'ana as "I was tempted" (Mallet-Gay \& Farhadi, 2016, 1:42:42).

Secondly, Farhadi's society, like all other patriarchal societies, defines woman as an object in need of protection. As Patricia Owen declares: "Cultural norms in patriarchal societies dictate that women need male protection from predatory males" (2018, p. 90). It seems a woman can be safe from all danger and fear when she is protected by a man. Thus, having accepted this reality of patriarchal society, Farhadi's female characters always need men as their protectors, no matter how strong the man is or how old he is. It can be a young boy like Sanam's son in The Salesman with whom R'ana feels at ease coming back home or a wretch addict like Firooze's husband in Beautiful City, their mere existence helps women to feel safe. When A'ala asks Firooze as to why she keeps the marital ring in her hand despite being a divorcee, she answers: "What do you think? How do I manage to live in such a place; with the help of this ring, with the help of an addict to make others believe he's my husband. Without a man, every night many will come to you" (Taghipoor \& Farhadi, 2004, 1:15:52). Although Firooze's husband is good-for-nothing, his very sign in her hand keeps men away from her and mutes people making rumors similar to what was spread about Reyhane's mother and her bad reputation in Dancing in the Dust. Abolghasem's wife, another female character in the same movie, apparently has married Abolghasem to provide a male support for her daughter. She outspokenly tells this to her husband "I brought my daughter to your home since I was hopeful that you would treat her like a father" (Taghipoor \& Farhadi, 2004, 1:06:56). Both these women, Firooze and Abolghasem's wife, are portrayed as much wiser than their husbands but still in need of them to live in the unsafe society. The need which Mojde in Fireworks Wednesday feels while saying "I wish dad were here" (Saadatian \& Farhadi, 2006, 00:31:00). Telling her sister about her husband's affair, she thinks only a man's protection can solve her problem. It might be the reason behind sleeping near her son, 
Amirali, at the end of the movie. It seems as if Amirali's company makes Mojde feel safe. Simin, her foil character in the movie, also, after being annoyed by two bikers, returns to Morteza, despite recently breaking up with him. Morteza is not available anymore, which shows like other male shelters in Farhadi's oeuvre, this one is unstable, too.

Razzie in A Separation, on the other hand, is always worried about her husband's feeling toward her work, therefore, she needs to keep it as a secret, what most of the female characters in Farhadi's cinema do. It may allude to the fact that not only do women feel unsafe in the society but also they are not at ease at home. Reyhane in Dancing in the Dust cannot talk to Nazar about her background and gets divorce rather than revealing her secret. Sepide in About Elly always has something furtive from her husband while Celine of The Past and Mojde in Fireworks Wednesday need to keep their suspicions against their spouses secret. And lastly, R'ana in The Salesman cannot retell the details of the accident to Emad. All these women like to picture a better future by ignoring their past, as if their husbands' awareness would push them back and stop them from moving forward. In his interview with Zeinab Kazemkhah, Farhadi introduces his female characters as forerunners. He believes that women, the ones with the potential of mothering, always surpass the past far easier than men do.

As the third consequence it can be mentioned that being a woman in a patriarchal society puts female characters at the center of others' observation and, accordingly, judgment. If a male character were to take the place of the female one, the entire or half of Farhadi's challenges would become void. Fireworks Wednesday and The Past seem to retell the same story in different settings. Having been left alone by their husbands, both Simin and Marie have to keep their love affairs secret. In this regard, the modern setting of France is not much different from that of the tradition-bound Iran. Female characters in both settings are exposed to others' judgment, while neither their separations nor their being loved by new men is on their own accord. Having been forced to neglect their love of their ex-husbands, they are doomed to live with the guilt feeling of ruining another woman's life. It is obvious that if these female characters were replaced by men, their problems would be meaningless and such judgments would be out of question.

Another example of women fated to be prejudged is Reyhane whose life is ruined because of rumors around her mother. She is doomed not to have a happy life with her lover, Nazar. Both at home and at work, Nazar is pushed to divorce her by virtue of the rumors around her mum. R'ana of The Salesman is haunted by the fear of such rumors while none of them, neither Reyhane nor R'ana, is guilty. However, they are women, fragile objects prone to be damaged easily. Additionally, in About Elly, if the central character were a man, the story would not be that much complicated, hence, nobody could form these judgments. After getting lost, different assumptions about Elly's being a prostitute are expressed:

Amir: 'If she has a fiancée why on earth she has come to the North with us?'

Nazi: 'She does not seem to be such a girl.'

Peyman: 'She does, but we were too idiot [to believe her].' (Farhadi \& Farhadi, 2009, 1:26:51)

Manoochehr: 'Look how a twenty-year-old girl put us all in trouble? (Farhadi \& Farhadi, 2009, 1:27:45)

Peyman: "The guy had had a fiancée while coming here in search of a husband ... She betrayed her husband." (Farhadi \& Farhadi, 2009, 1:40:35)

Manoochehr: "All [her help] was a mere show." (Farhadi \& Farhadi, 2009, 1:41:05)

The forth consequence of patriarchy refers to this danger of prostitution, what nearly all female characters of Farhadi seem to be exposed to. They can be easily labeled as damaged girls or prostitutes, a good example of which is Reyhane of Dancing in the Dust, whose lover, Nazar, says: "If I divorce her, she'll be doomed" (Taghipoor \& Farhadi, 2003, 00:6:32). He believes that after their separation, Rehyane's life will be a replica of her apparently prostitute mother or at least at the risk of infamy. It needs to be mentioned that this is typical of Iranian movies, i.e. when a woman loses the breadwinner of the family, rumors are that she is to be a prostitute to make a living and has to bear the grave looks of people.

Despite being a divorcee, Firooze of Beautiful City keeps the wedding ring in her finger to save herself from this danger, as quoted earlier. She believes that without the wedding ring she will be easily turned into a prostitute. Besides, Naima in The Past faces a similar accusation by Celine who suspects Naima and Samir, her husband, to be in a secret relationship while Lucie incriminates her mother by these words: "since my birth, she married thrice, it is the same old story, somebody comes and after a while leaves" (Mallet-Gay\& Farhadi, 2013, 00:29:52). As it is clear, she easily accuses her mother of prostitution. Finally, the best example of this reality in The Salesman is R'ana. Infamy is her fear of life, leading her not to speak about her accident at all. She feels unsafe about others' judgment. "Who knows? How does she/ he understand it?" are the questions she asks repetitively, through the movie. On the other hand, in this movie, Ahoo is a foil character for both Sanam and R'ana, who are susceptible to be defined by society like her. Ahoo is a single mother who becomes "a damaged woman," in Emad's words, to live off in this unsafe society.

To Farhadi, prostitution is an inevitable consequence of poor living conditions. The dialogue between Nazar and his colleague best indicates this fact:

Nazar: Reyhane [whom he is forced to divorce] is innocent.

Amri: Her mum was innocent once, too. (Taghipoor \& Farhadi, 2003, 00:12:30)

This mother and daughter are doomed to have such a life since society deprives them of other options. This is what makes Farhadi respectful toward prostitutes, as he mentions it in his 2016 interview with BBC. Different scholars have the same opinion about this issue. Mary Walek Atwell (2014) has gathered some of their ideas in her article entitled 
"Prostitution, Law." As she mentions: Barry thinks prostitution and sexual slavery is the consequence of patriarchal society which justifies such pleasure for its male members. Daris, having had an anthropological study of the issue in different societies, comes to this conclusion that "woman [who has] chosen a career in prostitution is contradicted by the reality of her powerlessness" and Zaplin (2015) refers to it as "a means of survival in the streets" (p. 1315). All of them put the blame on society and Farhadi seems to be on the same side. This danger is always available in his movies, hinting that prostitution is the force, not the choice of life.

\section{Denial AND Victim-Blaming: IgNORING OTHER WOMEn to FEEL RELAXED}

As discussed earlier, women in Farhadi's depicted society always feel uneasy. This is not just a simple feeling but a reality of their society from which none of them can escape. Although some of them run into different shelters such as male protection, they seem to be doomed to live with its fear in their mind forever. It is the story of their everyday life either as a victim or as a witness. When it is their own turn, thanks to the defense mechanism of denial, they try their best to act as if nothing has happened. Surrounded by this fact in every moment of their life, their egos seek refuge in this psychological shelter:

Denial is a defense mechanism used to avoid dealing with a painful reality. Denial is said to be a conscious behavior because people are aware on some level that they are denying. The person may pretend or act as if problems do not exist, trying to protect themselves from an unpleasant situation such as addiction or abuse. (Kittelson et al., 2005, p. 40)

Such people, by employing the defense mechanism of denial, prefer to neglect reality, consciously. This consciousness is obvious in the dialogue of the two sisters in Fireworks Wednesday:

Mojde: You are a kid who takes everything as a joke.

Mahshid: What on earth have you done by taking all things seriously? (Saadatian \& Farhadi, 2006, 00:26:04)

Mahshid tries to employ a carefree attitude toward the problem, while her words and actions show something else.

However, as witnesses, women find a better refuge in victim-blaming, the sociological term referring to the situation in which the victim is blamed rather than the criminal. The best example of this is again Mahshid who blames her sister for her husband's betraying her. In a previous scene she is heard on the phone checking her own husband as not to gaze at other women. This signifies her fear of seeing the same behavior from her own husband. In other words, women like Mahshid attempt to deceive themselves. They want to believe such problems are so far from them. This wrong perception is what happens recurrently in Farhadi's oeuvre, as highlighted below.

Nazar's mother insists that he must divorce his wife or his family will ignore him. He argues the consequence of this separation, saying that Reyhane is innocent and leaving her alone will force her to take after her mother's life as a prostitute. Nazar's mother is so stubborn and denies the harsh reality of society just mentioned by her son. Nazar, on the other hand, tries to give Reyhane a chance. Eventually his mother is the big winner. Her crocodile tears make Nazar change his mind and divorce Reyhane. Some signs in the last scene of having Reyhane in the frame signify that Nazar was right. Reyhane is portrayed in the same mise en scene in which her mother was putting clothes on the lines at the beginning of the movie. Her top to toe black outfit is replaced with a white one which is the code of a radical change and her innocence is lost under a light makeup, a meaningful look, and eyes full of tears. Her life is ruined, as Nazar predicted before, and the blame of this loss lies with Nazar's mother.

Another woman is Abolghasem's wife in Beautiful City who stands in front of Firooze's promising future with A'ala. Firooze has fallen in love with A'ala; she takes off her wedding ring and asks him not to steal anymore because she does not like him to be behind bars again. However, Abolghasem's wife asks Firooze to force A'ala to marry her daughter. This marriage will be considered as Abolghasem's daughter's blood money who was murdered by Akbar, Firooze's brother. Thus, Firooze is forced to neglect all her fantasies of a future happy life with A'ala for the sake of her brother's life. This is the dialogue when her lover, A'ala, asks her to make a decision after Abolghasem's wife's offer:

A'ala: I'm crazy, if you say I will marry her. What should I do, Firooze?

Firooze: She is a good girl

A'ala: Are you bad?

Firooze: Me? I have a child. I'm several years your senior. I'm not suitable for you

A'ala: How come? Of late you were!

Firooze: When did I say I'm suitable for you? Don't misinterpret my attention in the last couple of days as my love for yourself. It was all for the sake of Akbar that you were dying to save.

A'ala: You are lying, you are lying. (Taghipoor \& Farhadi, 2004, 1:18:44)

The defense mechanism of denial is what Firooze finds shelter in. She intentionally ignores her love for A'ala and the one responsible for this is Abolghasem's wife. She might not be aware of Firooze's love for A'ala and refrains from noticing it even after Firooze bursts into tears while hearing her decision. She acts as if her own problems of life make her blind to Firooze and her feelings. The same behavior can be seen in the first movie, Dancing in the Dust. When the judge asks Reyhane as to why she seeks divorce, she replies: "I do not like him." Nazar complains: "Don't you like me?" and she answers back "kidding" while winking (Taghipoor \& Farhadi, 2003, 00:15:15). 
The same is true about all middle-class female characters in The Fireworks Wednesday. Mojde and Simin are always being backbitten by other women in their neighborhood, the first one because of her bad temper and the latter one because of her living alone. In Mojde's case, her neighbor recalls her by the word "the crazy woman" and even her sister, Mahshid, cannot understand her. When Mojde wants to pour her heart out, Mahshid insists that the problem is Mojde, herself:

Mahshid: You idiot, such a good and calm husband [you have].

Mojde: He is my husband, I know him. Why do you talk in his favor? (Saadatian \& Farhadi, 2006, 00:30:45)

This discussion continues the same for several minutes. When Mojde makes her sure about Morteza's having affair; Mahshid says; "with your [messy] life and house..." (Saadatian \& Farhadi, 2006, 00:31:57). Mahshid believes Mojde shares the blame for Morteza's infidelity while a male character like Mahmood, Morteza's colleague, addresses him thus: "I think you must have done something wrong because your wife is not crazy to come here and spy on you since noon" (Saadatian \& Farhadi, 2006, 00:58:15). He does believe Mojde must have had a good reason to stand hours outside her husband's office. Simin, her foil character, on the other hand, is asked to move from that apartment because of the neighbors' complaints, despite all her attempts to be always helpful to them. It seems as if nobody cares about her. Her very presence in that apartment, however, is threatening Mojde's life, since she is too intimate with Morteza. The opposite can be correct, too, Mojde stands on the way of her happiness. As a result, these two women's love for one man defines them as enemies. Roohangiz, the young servant, comes to an understanding about the danger of other women after getting familiar with them and their lifestyle.

The issue of a woman in opposition to another woman is not highlighted in A Separation. However, the different female characters come up against each other in this movie. Nader's neighbor who says Razzie had fainted the day before the accident is a case in point. After her report, Razzie is completely condemned. Simin's mother is another example who seems totally neglectful of her daughter and her decision of separation. While seeing Nader she says:

Mother: Not divorcing yet and already ignoring us.

Nader: I'm busy, mum.

Mother: People divorce their wife to get less busy. (Farhadi \& Farhadi, 2011, 00:47:02)

She talks to him with a sense of humor as if nothing has happened. It looks as if she wants not to lose the protection and support of this man.

This atmosphere is depicted clearly in The Past; the story of passing over sisters. Celine and Marie stand in the way of each other's love and happiness. Besides, Naima does not feel safe at work since Celine suspects her of having an affair with Samir.

Naima: She didn't like me since she was suspecting me.

Samir: Why did she suspect you?

Naima: Since you have given me a job regardless of the fact that I had no job permit. She thinks you and I are in an affair. (Mallet-Gay \& Farhadi, 2013, 1:43:37)

In the next scene, she continues: "She [Celine] used to do something to make you fire me" (Mallet-Gay \& Farhadi, 2013, 1:44:28). Assuming Naima as a rival, Celine did her best to irritate her. Instead, Naima gave her email address to Lucie since she wanted to send her mother's love letter to Celine. They both gave each other hard time without any attention to the feelings involved. It ended up in the worst imaginable thing; Celine had a suicide attempt in front of Naima's eyes. Lucie, on the other hand, was the one who ruined her mother's happy future. She sent her mother and Samir's love letters to Celine, possibly accounting for Celine's suicide attempt. Her mother recalls her by these words "let her come and see how she puts my life in a mess" (Mallet-Gay \& Farhadi, 2013, 1:06:47).

In About Elly, Asghar Farhadi narrates the story of two women: Elly who is known to nobody but Sepide, and Sepide who hides it. It is the only story in Farhadi's cinema in which a woman like Sepide tries to back up another woman, Elly. However, others force her, at the climax of the story, to stand in front of her. She lies to Elly's fiancé that she never mentioned his name while being invited to the trip to get familiar with Ahmad, Sepide's friend. The movie finishes with the sequence of having disappointed Sepide in the kitchen while at the background others are pulling their car stuck in the beach sand. Sepide still feels guilty and blames herself while others are involved in an outdoor problem.

In The Salesman, at the beginning of the movie, Ahoo's stuff is thrown away regardless of her insistence on not touching it. R'ana is the only one who has talked to her directly. She is totally neglectful of her feeling and right. Although Emad is doubtful about opening Ahoo's room's door, R'ana insists on opening it. She treats as if this intrusive action would not ever happen to her. Nevertheless, she experiences the same accident, in the following scenes, when instead of the stuff, her body is involved. Moreover, after cutting the play within the movie by Sanam, playing a prostitute (since Siavash, cannot get passed the sexual nature of her role) R'ana bursts into laughter ignoring Sanam's feeling. In several following parallel sequences, R'ana herself is the one ignored by other women after her accident; at the hospital, by the nurse stitching her head; at work, by Cathy playing her role in the play without informing her; and finally, by Sanam insisting on her coming back to work soon. Sanam directs R'ana:

Sanam: Tomorrow on, you need to come back to show, everything is in a mess, nobody knows what's he doing.

R'ana: Why? 
Sanam: I don't know, they all are unhappy, after all. You look better. Tomorrow come to the stage.

(Mallet-Gay \& Farhadi, 2016, 1:30:21)

The same old story is repeated in Farhadi's cinema. A woman ignoring another one's feeling asks her to act the way society requests. Sanam, as mentioned before, is the foil character of Ahoo, single mothers who have to live off in this unsafe society. Sanam is at the risk of being another Ahoo, however, she thinks R'ana's accident will never happen to her.

\section{CONCLUSION}

A semiotic study of Farhadi' cinema up to 2016 has shown that the society portrayed by him cannot be considered safe from the feminist perspective. In his society, like all patriarchal societies, female objectification is a norm. Men are permitted to treat these objects as they wish. Surprisingly, female characters in Farhadi's cinema usually behave as though no threat is around. The defense mechanism of denial is what they have chosen to manage to live on in such an unsafe society. This denial is too strong and sometimes leads to blaming the female victim of the accident. Such a behavior helps them to remain neglectful of other women and feel immune from the danger of society.

To a social realist like Asghar Farhadi, women are blamed in constructing such a society, if not more than male members, at least the same as them. R'ana of The Salesman is the best example to warn women not to ignore each other's plight, lest the worst might easily happen to you once.

\section{REFERENCES}

[1] Atwell, M. W. (2014). Prostitution, Law. In J. Michie, Reader's Guide to Social Science. London: Routledge. ISBN $=1135932263$

[2] Bulbeck, C. (1997). Living Feminism. Cambridge: Cambridge University Press. DOI./10.1017/cbo9780511552144

[3] BBC Persian. (2016). Parvande yek film. Retrieved from https://www.youtube.com/watch?v=ctPcWxU-WG4 (accessed 25/5/2019).

[4] Farhadi, A. (Producer), Farhadi A. (Director). (2009). About Elly. Iran: Simaye Mehr.

[5] Farhadi, A. (Producer), Farhadi A. (Director). (2011). A Seperation. Iran: Filmiran.

[6] Kazemkhah, Z. (2016). Sebtember 14. Asghar Farhadi: Nacharam gahi fasele begiram va bazgardam [Farhadi, Asghar: Sometimes, I need to keep distance and come back later]. Tehran, E'temad. : No. 3625, P. 9. http://www.magiran.com/npview.asp?ID=3430524 (accessed 25/5/2019).

[7] Kiang, J. (2017, January 25). Asghar Farhadi’s 'The Salesman' Is Compelling, But Falls Just Short Of Greatness [Review]. The Playlist Retrieved from https://theplaylist.net/asghar-farhadi-the-salesman-compelling-falls-short-greatness-20170125/ (accessed 25/5/2019).

[8] Kittleson, M. J., Denkmire, H., Kane, W., \& Rennegarbe, R. (2005). The Truth about Fear and Depression. NY, New York: Infobase Publishing. ISBN=0816068615.

[9] Metz, Christian. (2011). Language and Cinema (D. J. Umiker-Sebeok Trans.). Berlin: Walter de Gruyter. ISBN 3110816040 , 9783110816044

[10] Mallet-Guy, A. (Producer), Farhadi A. (Director). (2016). The Salesman. France: Momento Films.

[11] Mallet-Guy, A. (Producer), Farhadi A. (Director). (2013). The Past. France: Momento Films.

[12] Owen, R. P. (2018). Gender and Patriarchy in the Films of Muslim Nations. Noeth Carolina, Jefferson: MacFarland \& Company, Inc. ISBN-13: 978-1476667874

[13] Riddle, I. D. (2015). Moving Beyond Duality: Enough for Us All. Boomington: iUniverse. Volume Three. ISBN 1491782757.

[14] Roth, L. (2013). Film Semiotics, Metz, and Leone's Trilogy. London: Routledge. DOI: 10.4324/9781315855714.

[15] Saadatian, J. (Producer), Farhadi A. (Director). (2006). Fireworks Wednesday. Iran: Hedayat Films.

[16] Shirazi, M., Duncan, P., \& Freehling-Burton, K. (2017). Gender, Nation and Belonging: Representing Mothers and Maternal in Asghar Farhadi's A Separation. $\quad$ Atlantis. $\quad$ Vol 37, No 1. ISSN: 1715-0698 http://journals.msvu.ca/index.php/atlantis/article/view/2864 (accessed 25/5/2019).

[17] Taghipoor, I. (Producer), Farhadi A. (Director). (2004). Beautiful City. Iran: Neshane Films.

[18] Taghipoor, I. (Producer), Farhadi A. (Director). (2003). Dancing in the Dust. Iran: Neshane Films.

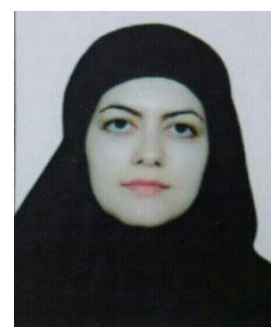

Ma'soome Sehat, was born in Yazd-Iran in 1986. She is currently a postgraduate student of English Literature in Yazd University, Yazd-Iran.

She is a senior lecturer in several language institutes in Yazd with more than 7 years of experience. She is currently working in Mehryar Language Institute in Yazd. She is the author of two articles in film studies and comparative literature. Her areas of interest are Comparative Literature, Film Studies and Cultural Studies. 


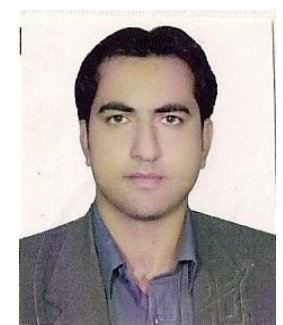

Hossein Jahantigh, was born in Zahedan-Iran in 1980. He is assistant professor of English Literature in Yazd University, Yazd-Iran.

He has a teaching experience of more than 15 years at university level in Iran. He is the author, translator and editor of several books related to drama and fiction: Macbeth with an Introduction to Drama (Yazd, Yazd: Andishmandane Yazd 2014), and The Plough and The Stars (Translated into Persian, Yazd, Yazd: Andishmandane Yazd 2015). He has also written several articles in the areas of cultural studies, cinema and drama. His areas of interest and research include cultural studies and cinema. 